Pacific Journal of Mathematics

A RESULT CONCERNING INTEGRAL BINARY QUADRATIC 


\section{A RESULT CONCERNING INTEGRAL BINARY QUADRATIC FORMS}

\section{William Edward Christilles}

This paper contains an extension of an earlier work by Dickson ([1], p. 95), in which the following theorem was proven:

THEOREM 1. (Dickson's Theorem). If a number is represented properly by a form $[a, b, c]$ of discriminant $D=4 a c-b^{2}$, then any divisor of that number is represented by some form of the same discriminant $D$.

Definition. ([1], p. 68). A positive form $[a, b, c]$ is called reduced if $-a<b \leqq a, c \geqq a$, with $b \geqq 0$ if $c=a$.

As a consequence of the above definition it follows that $4 a^{2} \leqq 4 a c=$ $D+b^{2} \leqq D+a^{2}, 3 a^{2} \leqq D$, and finally $a \leqq \sqrt{(1 / 3) D}$

THEOREM 2. Let $M$ be properly represented by the integral positve definite quadratic form $a \alpha^{2}+b \alpha \gamma+c \gamma^{2}$ of discriminant $D=4 a c-b^{2}$. If $M \leqq 3 D / 16$ and $(D, M)=1$, then in every factorization of $M$ one of the factors is $a_{i}$, one of the minimal values of a primitive quadratic form of discriminant $D$. In other words, $M=M_{1} M_{2}$ where $M_{1}$ is a unit or a prime and $M_{2}$ is the product of no more than two $a_{i}$.

Proof. According to the remark following the definition $a_{i} \leqq \sqrt{D / 3}$, where equality for a primitive reduced form is possible only if $a_{i}=$ $b_{i}=c_{i}=1$ and hence $D=3$ so that the inequality $0<M \leqq 3 D / 16$ cannot be satisfied. Thus $a_{i}<\sqrt{\bar{D} / 3}$.

Now assume $M=r_{1} r_{2}$. Then according to Theorm 1 it follows that

$$
r_{1}=a_{i} \alpha_{i}^{2}+b_{i} \alpha_{i} \gamma_{i}+c_{i} \gamma_{i}^{2}, \quad r_{2}=a_{j} \alpha_{j}^{2}+b_{j} \alpha_{j} \gamma_{j}+c_{j} \gamma_{j}^{2}
$$

where the two quadratic forms are primitive reduced forms of discriminant D. Hence

$$
\begin{aligned}
\left(4 a_{i} r_{1}\right)\left(4 a_{j} r_{2}\right) & =\left[\left(2 a_{i} \alpha_{i}+b_{i} \gamma_{i}\right)^{2}+D \gamma_{i}^{2}\right]\left[\left(2 a_{j} \alpha_{j}+b_{j} \gamma_{j}\right)^{2}+D \gamma_{j}^{2}\right] \\
& =\left(\beta_{i}^{2}+D \gamma_{i}^{2}\right)\left(\beta_{j}^{2}+D \gamma_{j}^{2}\right)=16 a_{i} a_{j} M \\
& <16(D / 3) M \leqq(16 D / 3)(3 D / 16)=D^{2}
\end{aligned}
$$

where $\beta_{i}=\left(2 a_{i} \alpha_{i}+b_{i} \gamma_{i}\right)$ and $\beta_{j}=\left(2 a_{j} \alpha_{j}+b_{j} \gamma_{j}\right)$. This implies that $\gamma_{i} \gamma_{j}=0$, say $\gamma_{i}=0$, and therefore $r_{1}=a_{i}$.

To prove the final statement of the theorem, assume $M \neq \alpha_{i}$ and

Received November 21, 1963. The author is indebted to the referee for the suggested revision of both the statement and the proof of Theorem 2 . 
let $r_{2}$ be a minimal factor of $M$ so that $r_{2} \neq a_{j}$. If $M_{1}$ is any primefactor of $r_{2}$, then $M=M_{1} M_{2}$ where $M_{2}=\left(M / r_{2}\right)\left(r_{2} / M_{1}\right)=a_{i} a_{j}$.

\section{REFERENCE}

1. L. E. Dickson, Introduction to the Theory of Numbers, Dover Publications, Inc., New York, 1929.

St. Mary's University, San ANTonio, TeXaS 


\section{PACIFIC JOURNAL OF MATHEMATICS}

\section{EDITORS}

\author{
Robert Osserman \\ Stanford University \\ Stanford, California
M. G. Arsove
University of Washington
Seattle 5 , Washington

\author{
J. DugundJI \\ University of Southern California \\ Los Angeles 7, California
}

Lowell J. Paige

University of California

Los Angeles 24, California

\section{ASSOCIATE EDITORS}
E. F. BECKENBACH
B. H. NeumanN
F. WOLF
K. YOSIDA

\section{SUPPORTING INSTITUTIONS}

\author{
UNIVERSITY OF BRITISH COLUMBIA \\ CALIFORNIA INSTITUTE OF TECHNOLOGY \\ UNIVERSITY OF CALIFORNIA \\ MONTANA STATE UNIVERSITY \\ UNIVERSITY OF NEVADA \\ NEW MEXICO STATE UNIVERSITY \\ OREGON STATE UNIVERSITY \\ UNIVERSITY OF OREGON \\ OSAKA UNIVERSITY \\ UNIVERSITY OF SOUTHERN CALIFORNIA
}

\author{
STANFORD UNIVERSITY \\ UNIVERSITY OF TOKYO \\ UNIVERSITY OF UTAH \\ WASHINGTON STATE UNIVERSITY \\ UNIVERSITY OF WASHINGTON \\ * * * * \\ AMERICAN MATHEMATICAL SOCIETY \\ CALIFORNIA RESEARCH CORPORATION \\ SPACE TECHNOLOGY LABORATORIES \\ NAVAL ORDNANCE TEST STATION
}

Mathematical papers intended for publication in the Pacific Journal of Mathematics should by typewritten (double spaced), and on submission, must be accompanied by a separate author's résumé. Manuscripts may be sent to any one of the four editors. All other communications to the editors should be addressed to the managing editor, L. J. Paige at the University of California, Los Angeles 24, California.

50 reprints per author of each article are furnished free of charge; additional copies may be obtained at cost in multiples of 50 .

The Pacific Journal of Mathematics is published quarterly, in March, June, September, and December. Effective with Volume 13 the price per volume (4 numbers) is $\$ 18.00$; single issues, $\$ 5.00$. Special price for current issues to individual faculty members of supporting institutions and to individual members of the American Mathematical Society: $\$ 8.00$ per volume; single issues $\$ 2.50$. Back numbers are available.

Subscriptions, orders for back numbers, and changes of address should be sent to Pacific Journal of Mathematics, 103 Highland Boulevard, Berkeley 8, California.

Printed at Kokusai Bunken Insatsusha (International Academic Printing Co., Ltd.), No. 6, 2-chome, Fujimi-cho, Chiyoda-ku, Tokyo, Japan.

PUBLISHED BY PACIFIC JOURNAL OF MATHEMATICS, A NON-PROFIT CORPORATION

The Supporting Institutions listed above contribute to the cost of publication of this Journal, but they are not owners or publishers and have no responsibility for its content or policies. 


\section{Pacific Journal of Mathematics}

\section{Vol. 14, No. $3 \quad$ July, 1964}

Erik Balslev and Theodore William Gamelin, The essential spectrum of a class of ordinary differential operators . . . . . . . . . . . . . . . . . . . .

James Henry Bramble and Lawrence Edward Payne, Bounds for derivatives in

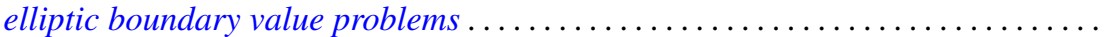

Hugh D. Brunk, Integral inequalities for functions with nondecreasing

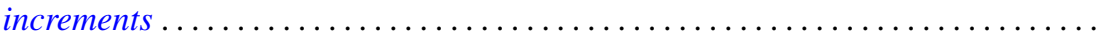

William Edward Christilles, A result concerning integral binary quadratic

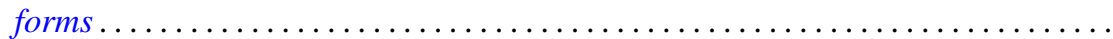

Peter Crawley and Bjarni Jónsson, Refinements for infinite direct decompositions of

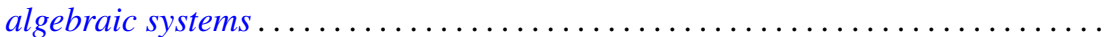

Don Deckard and Carl Mark Pearcy, On continuous matrix-valued functions on a Stonian space.

Raymond Frank Dickman, Leonard Rubin and P. M. Swingle, Another

characterization of the $n$-sphere and related results $\ldots \ldots \ldots \ldots \ldots \ldots$

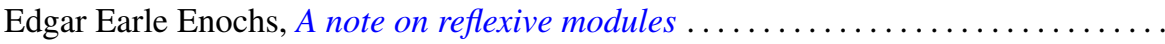

Vladimir Filippenko, On the reflection of harmonic functions and of solutions of the

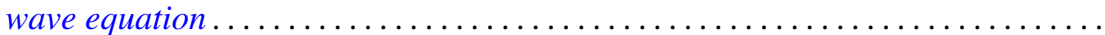

Derek Joseph Haggard Fuller, Mappings of bounded characteristic into arbitrary

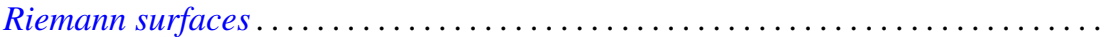
895

Curtis M. Fulton, Clifford vectors . . . . . . . . . . . . . . . . . . . . . . . . . . . . . . 917

Irving Leonard Glicksberg, Maximal algebras and a theorem of Radó . .

919

Kyong Taik Hahn, Minimum problems of Plateau type in the Bergman metric

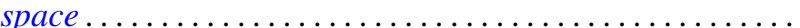

A. Hayes, A representation theory for a class of partially ordered rings...

J. M. C. Joshi, On a generalized Stieltjes trasform

J. M. C. Joshi, Inversion and representation theorems for a generalized Laplace transform ...

Eugene Kay McLachlan, Extremal elements of the convex cone $B_{n}$ of functions ...

Robert Alan Melter, Contributions to Boolean geometry of p-rings ...

James Ronald Retherford, Basic sequences and the Paley-Wiener criterion . . . . . . . 1019

Dallas W. Sasser, Quasi-positive operators. .

Oved Shisha, On the structure of infrapolynomials with prescribed coefficients ..

Oved Shisha and Gerald Thomas Cargo, On comparable means

Maurice Sion, A characterization of weak ${ }^{*}$ convergence ........

Morton Lincoln Slater and Robert James Thompson, A permanent inequality for

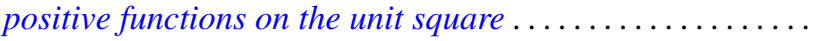

David A. Smith, On fixed points of automorphisms of classical Lie algebras ...

Sherman K. Stein, Homogeneous quasigroups ................

J. L. Walsh and Oved Shisha, On the location of the zeros of some infrapolynomials with prescribed coefficients .

Ronson Joseph Warne, Homomorphisms of $d$-simple inverse semigroups with identity . 